\title{
Panoramic Radiobiological Modelling of the Contribution of Concomitant Chemotherapy to Biological Effective Dose in Squamous Cell Carcinoma
}

\author{
Laura Pettit $^{1}$, S. Meade ${ }^{1}$, P. Sanghera ${ }^{1,2}$, J. Glaholm ${ }^{1,2}$, R. M. Wyatt ${ }^{1} \&$ A. Hartley ${ }^{1,2}$ \\ ${ }^{1}$ Hall-Edwards Radiotherapy Research Group, Queen Elizabeth Hospital, Birmingham, UK \\ ${ }^{2}$ Institute of Head and Neck Studies and Education (InHANSE), University of Birmingham, Birmingham, UK \\ Correspondence: Laura Pettit, Hall-Edwards Radiotherapy Research Group, Queen Elizabeth Hospital, \\ Birmingham, UK. E-mail: 1.pettit@nhs.net
}

Received: October 26, $2013 \quad$ Accepted: November 26, $2013 \quad$ Online Published: January 1, 2014
doi:10.5539/cco.v3n1p1
URL: http://dx.doi.org/10.5539/cco.v3n1p1

\begin{abstract}
Objective: Attempts have been made to model the contribution of concomitant chemotherapy to radiotherapy in terms of biological effective dose (BED) for the major squamous cell carcinoma (SCC) sub-sites. Despite SCC's sharing common aetiology, different concomitant chemoradiotherapy regimens are used in clinical practice. This study aims to compare the contribution of chemotherapy to radiotherapy in terms of BED across the major SCC sub-sites using two different radiobiological models; the intuitive and Poisson methods for its calculation.
\end{abstract}

Methods: Phase 3 trials of radiotherapy versus chemoradiotherapy using conventional fractionation in SCC of the head and neck, lung, cervix, oesophagus and anus were identified. The contribution of chemotherapy (tBEDc) was modeled using both the intuitive and the Poisson model to give a weighted BED in Gray.

Results: Weighted tBEDc using the intuitive model were $8.6 \mathrm{~Gy}_{10}$ for head and neck, $6.3 \mathrm{~Gy}_{10}$ for lung, $6.3 \mathrm{~Gy} 10$ for cervix and $7.8 \mathrm{~Gy}_{10}$ for anus. The weighted tBEDc using the Poisson model were $1.8 \mathrm{~Gy}_{10}$ for head and neck, $0.9 \mathrm{~Gy}_{10}$ for cervix and $2.1 \mathrm{~Gy}_{10}$ for anus.

Conclusion: There is a striking similarity for the value of tBEDc across SCC sub-sites within both models. In head and neck cancer tBEDc derived from the Poisson model is not associated with the same biological effect as the same BED administered as radiotherapy alone. Therefore at this sub-site, where there is good data on radiotherapy dose response in the curative dose range, the Poisson model may be of limited value. However, it may be preferred for sub-sites where such data is lacking.

Keywords: chemoradiotherapy, radiobiology, biological effective dose, squamous cell carcinoma, modelling

\section{Introduction}

Concomitant radical chemoradiotherapy is used commonly for squamous cell carcinoma (SCC) arising in the head and neck, lung, uterine cervix, oesophagus and anus (Pignon, le Maître, Maillard, Bourhis, \& MACH-NC Collaborative Group, 2009; Auperin et al., 2010; Chemoradiotherapy for Cervical Cancer Meta-Analysis Collaboration, 2008; Anonymous, 1996; Herskovic et al., 1992).

SCC arising at different anatomical sites may share similar aetiological factors; namely smoking and alcohol misuse. Human papilloma virus (HPV) has been implicated in the pathogenesis of SCC of the oropharynx, cervix and anus (Ang et al., 2010; Bosch, Lorincz, Muñoz, Meijer, \& Shah, 2002; De Vuyst, Clifford, Nascimento, Madeleine, \& Franceschi, 2009). Where such aetiological similarities occur, it is remarkable to note the difference in radiotherapy and concomitant chemotherapy doses employed in the curative setting to achieve similar local control outcomes seen, for example, 70 Gray in 35 fractions is commonly employed in the radical setting for head and neck SCC, whereas 50.4 Gray in 28 fractions achieves similar rates of local control in anal SCC. Although HPV positive oropharyngeal cancer has been shown to confer a better prognosis compared with HPV negative disease (3-year overall survival $82.4 \%$ versus $57.1 \% \mathrm{p}<0.001$ for tumours treated with chemoradiotherapy within the RTOG 0129 study) the prognostic implications in anal and cervical cancer are unknown, largely due to the small number of HPV negative tumours associated with these sub-sites (Ang et al., 2010; Zandberg, Bhargave, Badin, \& Cullen, 2013). 
Numerous attempts have been made to model the contribution of chemotherapy to radiotherapy in terms of the biological effective dose (BED) (Geh, Bond, Bentzen, \& Glynne-Jones, 2006; Hartley, Sanghera et al., 2010; Jones, \& Sanghera, 2007). Calculating the additional BED provided by chemotherapy is important in attempting to predict toxicity and allows comparison of different regimes. Jones and Dale refer to many of these studies as using the "intuitive" or "rule of thumb" method (Jones \& Dale, 2005). Briefly the observation that approximately a $1 \%$ increase in local control is seen with a $1 \%$ increase in BED is employed to calculate the chemotherapy contribution to local control (tBEDc). In sub-sites such as head and neck cancer, where there are several randomized trials of altered fractionation versus conventional radiotherapy alone, more extensive modeling is possible and weighted values for this dose gradient can be calculated (Fowler, Harari, Leborgne, \& Leborgne, 2003). Jones and Dale describe a second method employing the Poisson model for tumour control probability (TCP) (Jones \& Dale, 2005).

Given the similar aetiology of SCC sub-sites, this study aims to compare the contribution of synchronous chemotherapy to radiotherapy in terms of BED calculation across the major SCC sub-sites using both the intuitive and Poisson radiobiological models.

\section{Methods}

BED was calculated using the standard linear quadratic equation (Fowler et al., 2003):

$$
\operatorname{BED}=[\mathrm{D}(1+(\mathrm{d} /(\alpha / \beta)))]-\left[(0.693 / \alpha)\left(\left(\mathrm{T}-\mathrm{t}_{\mathrm{k}}\right) / \mathrm{t}_{\mathrm{p}}\right)\right]
$$

Equation 1

Where BED = biologically effective dose (Gy); $\mathrm{D}=$ total dose (Gy); $\mathrm{d}=$ dose per fraction (Gy); $\alpha / \beta=$ linear $(\alpha)$ and quadratic $(\beta)$ components of the linear-quadratic model $(\mathrm{Gy}) ; \mathrm{T}=$ overall treatment time (days); $\mathrm{t}_{\mathrm{k}}=$ 'kick-off' or onset of accelerated repopulation time (days); $t_{p}=$ average doubling time during accelerated repopulation (days).

The following parameters derived by Fowler were used for the purposes of this study (Fowler et al., 2003):

For tumour local control (tBED): $\alpha / \beta=10 \mathrm{~Gy} ; \alpha=0.3 \mathrm{~Gy}^{-1} ; \mathrm{t}_{\mathrm{k}}=22$ days, $\mathrm{t}_{\mathrm{p}}=3$ days.

The following ratio was derived from a radiobiological study of head and neck cancer (Hartley, 2011):

$\mathrm{S}_{\mathrm{t}}=$ the ratio of the percentage increase in local control to the percentage increase in $\mathrm{tBED}=1.2$.

Phase 3 prospective randomised controlled trials of conventionally fractionated radiotherapy versus chemoradiotherapy in SCC of the head and neck, lung, uterine cervix, oesophagus and anus were identified. Trials were included in this study if the total dose (D), dose per fraction (d) overall treatment time (T) and local control rates at 3 years were published. Trials that reported their results as complete response, partial response, stable disease or progressive disease were excluded. Studies were included if the concomitant agent was cisplatin, carboplatin, mitomycin-C, 5-flurouracil or a vinca alkaloid, either as a single agent or in combination. Trials were excluded if a different radiotherapy dose was employed between the two arms of the trial or if they were not published in English. Trials were then grouped by tumour sub-site. A list of excluded trials of conventionally fractionated radiotherapy versus conventionallyfractionated radiotherapy plus synchronous chemotherapy is provided in appendix 1 .

An additional 'boost' of radiotherapy was historically administered in anal cancer trials after a gap of 6 weeks (Anonymous, 1996; Bartelink, 1997). An analysis of the United Kingdom Coordinating Committee on Cancer Research (UKCCCR) ACT I trial failed to find evidence that such boosts improved local control after a 6 week gap (Glynne-Jones et al., 2011). Therefore, for the purposes of this study, delayed anal cancer boosts are not taken into account in the calculations.

The contribution of chemotherapy (tBEDc) was modeled using two different methods.

For the intuitive method: tBED for the common radiotherapy components of both arms of the studies was calculated using equation 1 . The percentage difference $(\Delta \%)$ in tBED was obtained by dividing the absolute observed percentage difference in local control by $\mathrm{S}_{\mathrm{t}}(1.2)$ (equation 2). tBEDc was then obtained by multiplying the radiotherapy component tBED by the percentage difference in tBED expressed as a decimal fraction (equation 3).

$$
\begin{array}{cc}
\Delta \% \mathrm{tBED}=\left(\Delta \% \mathrm{LC} / \mathrm{S}_{\mathrm{t}}\right) & \text { Equation } 2 \\
\mathrm{tBEDc}=\mathrm{tBED} *(\Delta \% \mathrm{tBED} / 100) & \text { Equation } 3
\end{array}
$$

A weighted tBEDc was obtained for each anatomical sub-site by weighting by the number of patients in each study.

For the Poisson method: The overall cytotoxic drug related cell kill $\left(\mathrm{E}_{\mathrm{c}}\right)$ was calculated using 3 year local control 
rates as tumour control probabilities for the radiotherapy alone and chemoradiotherapy arms of the trial using equation 4. The tBEDc was obtained by dividing $\mathrm{E}_{\mathrm{c}}$ by the $\alpha$ value of $0.3 \mathrm{~Gy}^{-1}$ (equation 5).

$$
\begin{array}{cc}
\mathrm{E}_{\mathrm{c}}=\ln \left(\ln \mathrm{TCP}_{1} / \ln \mathrm{TCP}_{2}\right) & \text { Equation 4 } \\
\mathrm{tBEDc}=\mathrm{E}_{\mathrm{c}} / \alpha & \text { Equation 5 }
\end{array}
$$

Where $\mathrm{E}_{\mathrm{c}}=$ the overall cytotoxic drug related cell kill (including all cycles of concomitant chemotherapy), $\ln =$ natural $\log , \mathrm{TCP}_{1}=$ Tumour control probability from the radiotherapy component (3 year local control rate), $\mathrm{TCP}_{2}=$ Tumour control probability from the chemoradiotherapy component (3 year local control rate).

For calculation of BED for cervical brachytherapy (low dose rate) equation 6 was used (Dale \& Carabe-Fernandez, 2005):

$$
\mathrm{BED}=\mathrm{RT}(1+2 \mathrm{R} / \mu(\alpha / \beta)) \quad \text { Equation } 6
$$

Where $\mathrm{R}=$ dose rate in Gy per hour, $\mathrm{T}=$ treatment time in hours and $\mu=$ DNA sublethal damage constant. $\mu=\ln 2 / t_{1 / 2}$ where $t_{1 / 2}=1.5$ hours (Potter et al., 2006).

\section{Results}

Randomised controlled trials of radiotherapy versus chemoradiotherapy using conventional fractionation are listed in Table 1 for head and neck, cervix, anus and lung. No oesophageal trials meeting the criteria for calculation and therefore inclusion were identified. BEDs were calculated using the equations (Pignon et al., 2009; Auperin et al., 2010; Chemoradiotherapy for Cervical Cancer Meta-Analysis Collaboration, 2008; Ang et al., 2010) described in the methods above. The weighted tBEDc using the intuitive model were: head and neck 8.6 $\mathrm{Gy}_{10}$, lung $6.3 \mathrm{~Gy}_{10}$, cervix $6.3 \mathrm{~Gy}_{10}$ and anus $7.8 \mathrm{~Gy}_{10}$. Lung cancer trials included SCC and other non-small cell histological types. The percentage of patients with SCC histology in each trial is shown below Table 1. 
Table 1. Derivation of Biologically Effective Dose contribution to tumour local control by chemotherapy (tBEDc) using phase 3 randomised controlled trials of conventionally fractionated radiotherapy versus chemoradiotherapy in squamous cell carcinoma of the head and neck, lung, cervix and anal cancer using the intuitive method

\begin{tabular}{|c|c|c|c|c|c|c|c|c|c|c|c|c|c|}
\hline Reference & Author & Year & Agent & $\mathrm{N}$ & $\begin{array}{l}\text { Total concurrent } \\
\text { chemotherapy dose }\end{array}$ & $\begin{array}{l}\text { Total } \\
\text { dose (Gy) }\end{array}$ & $\begin{array}{l}\text { Fractio } \\
\text { ns }\end{array}$ & OTT & $\mathrm{d}$ & $\begin{array}{l}\text { tBED } \\
\left(\mathrm{Gy}_{10}\right)\end{array}$ & $\begin{array}{l}\Delta \% \text { 3year } \\
\mathrm{LC}\end{array}$ & $\Delta \%$ tBED & $\begin{array}{l}\text { tBEDc } \\
\text { (Gy) }\end{array}$ \\
\hline \multirow[t]{6}{*}{$\mathrm{SCCHN}$} & Adelstein & 2000 & $\begin{array}{l}\text { Cisplatin/5- } \\
\text { FU }\end{array}$ & 100 & $\begin{array}{l}\text { Cisplatin } 160 \mathrm{mg} / \mathrm{m}^{2} \\
5 \text {-FU } 8000 \mathrm{mg} / \mathrm{m}^{2}\end{array}$ & 68 & 34 & 58 & 2 & 53.9 & 32 & 26.7 & 14.4 \\
\hline & $\begin{array}{l}\text { Dennis } \\
\text { Calais }\end{array}$ & $\begin{array}{l}2004 \\
1999\end{array}$ & $\begin{array}{l}\text { Carboplatin } \\
/ 5-\mathrm{FU}\end{array}$ & 226 & $\begin{array}{l}\text { Carboplatin } 840 \mathrm{mg} / \mathrm{m}^{2} \\
5 \text {-FU } 7200 \mathrm{mg} / \mathrm{m}^{2}\end{array}$ & 70 & 35 & 51 & 2 & 61.7 & 26 & 21.7 & 13.4 \\
\hline & Forastiere & 2003 & Cisplatin & $345^{\mathrm{a}}$ & Cisplatin $300 \mathrm{mg} / \mathrm{m} 2$ & 70 & 35 & 46 & 2 & 65.5 & 22 & 18.3 & 12.0 \\
\hline & Fountzilas & 2004 & Cisplatin & 86 & Cisplatin $300 \mathrm{mg} / \mathrm{m}^{2}$ & 70.2 & 39 & 50 & 1.8 & 61.3 & $42^{\mathrm{e}}$ & 35.0 & 21.4 \\
\hline & Grau & 2003 & $\mathrm{MMC}$ & 478 & MMC 15 mg/m² & 66 & 33 & 47 & 2 & 60.0 & 0 & 0 & 0 \\
\hline & Olmi & 2003 & $\begin{array}{l}\text { Carboplatin } \\
/ 5-\mathrm{FU}\end{array}$ & 127 & 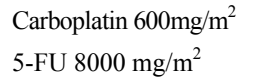 & 68 & 34 & 45 & 2 & 63.9 & 19 (2year) & 15.8 & 10.1 \\
\hline Total & & & & 1362 & & & & & & & & $\begin{array}{l}\text { Overall tBEDc } \\
\text { SCCHN }\end{array}$ & \\
\hline \multicolumn{14}{|l|}{ Lung } \\
\hline & Blanke $^{\mathrm{c}}$ & 1995 & Cisplatin & 215 & Cisplatin $210 \mathrm{mg} / \mathrm{m}^{2}$ & $64(\max )$ & 32 & 41 & 2 & 62.2 & 0 & 0 & 0 \\
\hline & Cakir $^{\mathrm{d}}$ & 2004 & Cisplatin & 176 & Cisplatin $200 \mathrm{mg} / \mathrm{m}^{2}$ & 64 & 32 & 43 & 2 & 60.6 & 25 & 20.8 & 12.6 \\
\hline & Zatlouka $^{\mathrm{e}}$ & 2004 & $\begin{array}{l}\text { Cisplatin / } \\
\text { Vinorelbine }\end{array}$ & 102 & $\begin{array}{l}\text { Cisplatin } 80 \mathrm{mg} / \mathrm{m}^{2} \\
\text { Vinorelbine } 62.5 \mathrm{mg} / \mathrm{m}^{2}\end{array}$ & 60 & 30 & 39 & 2 & 58.9 & 18 & 15 & 8.8 \\
\hline Total & & & & 493 & & & & & & & & $\begin{array}{l}\text { Overall } \\
\text { tBEDc Lung }\end{array}$ & 6.3 \\
\hline \multirow[t]{2}{*}{ Cervix } & $\begin{array}{l}\text { Eifel } \\
\text { Morris }\end{array}$ & $\begin{array}{l}2004 \\
1999\end{array}$ & $\begin{array}{l}\text { Cisplatin/5- } \\
\text { FU }\end{array}$ & 403 & $\begin{array}{l}\text { Cisplatin } 225 \mathrm{mg} / \mathrm{m}^{2} \\
5 \text {-FU } 12000 \mathrm{mg} / \mathrm{m}^{2}\end{array}$ & $\begin{array}{l}45 \mathrm{EBRT} \\
+40 \mathrm{LDR}\end{array}$ & 25 & 58 & 1.8 & 77.5 & $\begin{array}{l}16 \\
\text { (4-year) }\end{array}$ & 13.3 & 10.3 \\
\hline & Pearcey & 2002 & Cisplatin & 259 & Cisplatin $200 \mathrm{mg} / \mathrm{m}^{2}$ & $\begin{array}{l}45 \mathrm{EBRT} \\
+35 \mathrm{LDR}\end{array}$ & 25 & 50 & 1.8 & 74.5 & 0 & 0 & 0 \\
\hline Total & & & & 662 & & & & & & & & $\begin{array}{l}\text { Overall tBEDc } \\
\text { Cervix }\end{array}$ & 6.3 \\
\hline \multirow[t]{2}{*}{ Anal } & $\begin{array}{l}\text { UKCCC } \\
\text { R ACT } 1\end{array}$ & 1996 & $\begin{array}{l}\mathrm{MMC} / \\
5-\mathrm{FU}\end{array}$ & 585 & $\begin{array}{l}\text { MMC } 12 \mathrm{mg} / \mathrm{m} 2 \\
5-F U 8000 \mathrm{mg} / \mathrm{m} 2\end{array}$ & 45 & 25 & 32 & 1.8 & 45.4 & 22 & 18.3 & 8.3 \\
\hline & Bartelink & 1997 & $\begin{array}{l}\mathrm{MMC} / \\
5-\mathrm{FU}\end{array}$ & 110 & $\begin{array}{l}\text { MMC } 15 \mathrm{mg} / \mathrm{m} 2 \\
5-\mathrm{FU} 7500 \mathrm{mg} / \mathrm{m} 2\end{array}$ & 45 & 25 & 32 & 1.8 & 45.4 & 14 & 11.7 & 5.3 \\
\hline Total & & & & 695 & & & & & & & & $\begin{array}{l}\text { Overall } \\
\text { tBEDc Anal }\end{array}$ & 7.8 \\
\hline
\end{tabular}

${ }^{\mathrm{a}}$ arm one excluded (induction chemotherapy), ${ }^{\mathrm{b}}=\mathrm{SCC}: 51 \% \mathrm{RT}, 47 \% \mathrm{CRT},{ }^{\mathrm{c}}=\mathrm{SCC}: 73 \% \mathrm{RT}, 71 \% \mathrm{CRT},{ }^{\mathrm{d}}=\mathrm{SCC}: 46 \% \mathrm{RT}$, $44 \% \mathrm{CRT},{ }^{\mathrm{e}}=$ personal correspondence.

$\mathrm{N}=$ number of patients in study; Gy = Gray; OTT = overall treatment time of radiotherapy; $d=$ dose per fraction; tBED = biologically effective dose when considering local control from radiotherapy; $\mathrm{LC}=$ local control; 5-FU = 5-flurouracil; MMC $=$ mitomycin- $\mathrm{C} ; \Delta \%=$ difference in percentage. Rows in bold refer to weighted result for each tumour site.

Table 2 lists the same trials with the tBEDc derived using Poisson Modeling. BEDs were calculated using the equations (Pignon et al., 2009; Anonymous, 1996; Herskovic et al., 1992; Ang et al., 2010) described in the methods above. The weighted tBEDc using the Poisson model were: head and neck $1.8 \mathrm{~Gy}_{10}$, cervix $0.9 \mathrm{~Gy}_{10}$ and anus $2.1 \mathrm{~Gy}_{10}$. A weighted tBEDc for lung could not be calculated using the Poisson model as a local control rate of $0 \%$ was seen at 3 years intrials otherwise meeting the inclusion criteria for calculation by the intuitive method. 
Table 2. Derivation of Biologically Effective Dose contribution to tumour local control by chemotherapy (tBEDc) using phase 3 randomised controlled trials of conventionally fractionated radiotherapy versus chemoradiotherapy in squamous cell carcinoma of the head and neck, cervix and anus using the Poisson model

\begin{tabular}{|c|c|c|c|c|c|c|c|c|c|c|c|c|c|c|}
\hline Reference & Author & Year & $\mathrm{N}$ & $\begin{array}{c}\text { Total concurrent } \\
\text { chemotherapy dose }\end{array}$ & $\begin{array}{l}\text { Total } \\
\text { dose } \\
(G y)\end{array}$ & Fractions & OTT & $\mathrm{d}$ & $\begin{array}{l}\text { tBED } \\
\left(\mathrm{Gy}_{10}\right)\end{array}$ & $\begin{array}{c}\mathrm{TCP}_{1} \\
\mathrm{RT} \text { arm }\end{array}$ & $\begin{array}{l}\mathrm{TCP}_{2} \\
\mathrm{CRT} \\
\text { arm }\end{array}$ & $\mathrm{E}_{\mathrm{c}}$ & $\begin{array}{c}\text { No. } \\
\text { Cycles }\end{array}$ & $\begin{array}{c}\text { tBEDc } \\
(\mathrm{Gy})\end{array}$ \\
\hline \multicolumn{15}{|l|}{ SCCHN } \\
\hline & Adelstein & 2000 & 100 & Cisplatin $160 \mathrm{mg} / \mathrm{m}^{2}$ & 68 & 34 & 58 & 2 & 53.9 & 0.45 & 0.77 & 1.12 & 2 & 3.7 \\
\hline & & & & 5-FU $8000 \mathrm{mg} / \mathrm{m}^{2}$ & & & & & & & & & & \\
\hline & Dennis & 2004 & 226 & Carboplatin 840 & 70 & 35 & 51 & 2 & 61.7 & 0.34 & 0.6 & 0.75 & 3 & 2.5 \\
\hline & Calais & 1999 & & $\mathrm{mg} / \mathrm{m}^{2}$ & & & & & & & & & & \\
\hline & & & & 5 -FU $7200 \mathrm{mg} / \mathrm{m}^{2}$ & & & & & & & & & & \\
\hline & Forastiere & 2003 & $345^{\mathrm{a}}$ & Cisplatin $300 \mathrm{mg} / \mathrm{m}^{2}$ & 70 & 35 & 46 & 2 & 65.5 & 0.56 & 0.78 & 0.85 & 3 & 2.8 \\
\hline & Fountzilas & 2004 & 86 & Cisplatin $300 \mathrm{mg} / \mathrm{m}^{2}$ & 70.2 & 39 & 50 & 1.8 & 61.3 & $0.2^{b}$ & $0.62^{b}$ & 1.21 & 3 & 4.0 \\
\hline & Grau & 2003 & 478 & $\mathrm{MMC} 15 \mathrm{mg} / \mathrm{m} 2$ & 66 & 33 & 47 & 2 & 60.0 & - & - & 0 & 1 & 0 \\
\hline & Olmi & 2003 & 127 & $\begin{array}{c}\text { Carboplatin } 600 \\
\mathrm{mg} / \mathrm{m}^{2}\end{array}$ & 68 & 34 & 45 & 2 & 63.9 & 0.23 & 0.42 & 0.53 & 2 & 1.7 \\
\hline & & & & $5-F U ~ 8000 \mathrm{mg} / \mathrm{m}^{2}$ & & & & & & & & & & \\
\hline Total & & & 1362 & & & & & & & & & & $\begin{array}{c}\text { Overall } \\
\text { tBEDc } \\
\text { SCCHN }\end{array}$ & 1.8 \\
\hline \multirow[t]{5}{*}{ Cervix } & Eifel & 2004 & 403 & Cisplatin $225 \mathrm{mg} / \mathrm{m}^{2}$ & 45 EBRT & 25 & 58 & 1.8 & 77.5 & 0.2 & 0.36 & 0.45 & 3 & 1.5 \\
\hline & Morris & 1999 & & $5-F U 12000 \mathrm{mg} / \mathrm{m}^{2}$ & + & & & & & & & & & \\
\hline & & & & & $40 \mathrm{LDR}$ & & & & & & & & & \\
\hline & Pearcey & 2002 & 259 & Cisplatin $200 \mathrm{mg} / \mathrm{m}^{2}$ & $\begin{array}{c}45 \text { EBRT } \\
+\end{array}$ & 25 & 50 & 1.8 & 74.5 & - & - & 0 & 5 & 0 \\
\hline & & & & & $35 \mathrm{LDR}$ & & & & & & & & & \\
\hline Total & & & 662 & & & & & & & & & & $\begin{array}{l}\text { Overall } \\
\text { tBEDc } \\
\text { Cervix }\end{array}$ & 0.9 \\
\hline \multirow[t]{2}{*}{ Anal } & $\begin{array}{c}\text { UKCCCR } \\
\text { ACT } 1\end{array}$ & 1996 & 585 & $\begin{array}{l}\mathrm{MMC} 12 \mathrm{mg} / \mathrm{m}^{2} \\
5-\mathrm{FU} 8000 \mathrm{mg} / \mathrm{m}^{2}\end{array}$ & 45 & 25 & 32 & 1.8 & 45.4 & 0.39 & 0.61 & 0.64 & 2 & 2.1 \\
\hline & Bartelink & 1997 & 110 & $\begin{array}{l}\text { MMC } 15 \mathrm{mg} / \mathrm{m}^{2} \\
5-\mathrm{FU} 7500 \mathrm{mg} / \mathrm{m}^{2}\end{array}$ & 45 & 25 & 32 & 1.8 & 45.4 & 0.54 & 0.68 & 0.47 & 2 & 1.6 \\
\hline Total & & & 695 & & & & & & & & & & $\begin{array}{c}\text { Overall } \\
\text { tBEDc } \\
\text { Anal }\end{array}$ & 2.1 \\
\hline
\end{tabular}

${ }^{\mathrm{a}}$ arm one excluded (induction chemotherapy), ${ }^{\mathrm{b}}=$ personal correspondence.

$\mathrm{N}=$ number of patients in study; Gy = Gray; OTT = overall treatment time of radiotherapy; $\mathrm{d}=$ dose per fraction; tBED = biologically effective dose when considering local control from radiotherapy; TCP = Tumour control probability; $\mathrm{RT}=$ Radiotherapy $\mathrm{CRT}=$ Chemoradiotherapy $\mathrm{E}_{\mathrm{c}}=$ overall cytotoxic drug related cell kill 5-FU $=$ 5-flurouracil; $\mathrm{MMC}=$ mitomycin-C; $\Delta \%=$ difference in percentage; $\mathrm{SCCHN}=$ Squamous cell carcinoma of the head and neck; SCC = squamous cell carcinoma, LDR = low dose rate. Rows in bold refer to weighted result for each subsite.

Appendix 1 lists the excluded phase 3 trials using conventionally fractionated radiotherapy and the reasons for ineligibility.

\section{Discussion}

Although the results obtained from the two models differed significantly, the similarity of the magnitude of the contribution of synchronous chemotherapy in terms of BED (tBEDc) across anatomical sub-sites within each of the two models is striking. Taking the example of the intuitive method, tBEDc ranged from its lowest value of $6.3 \mathrm{~Gy}_{10}$ in lung and cervical cancer to the highest value of $8.6 \mathrm{~Gy}_{10}$ in head and neck cancer. This difference of $2.3 \mathrm{~Gy}_{10} \mathrm{BED}$ is approximately equivalent to a single 2 Gy fraction. Based on these results it appears that for 
SCC arising in the head and neck, anus, uterine cervix and lung, synchronous chemotherapy adds between 4.5 and 6.8 Gy in 2 Gray fractions (EQD2) (Lee, Forey, \& Coombs, 2012). However, there are many limitations to this appealing yet simplistic analysis.

In the intuitive method, radiosensitivity and repopulation parameters have been assumed to be identical for each of the anatomical sub-sites. This is unlikely to be the case given not only the heterogeneity of tumours within each sub-site but also the different tumour micro-environments at the varied anatomical locations. Although these tumours do share common aetiological factors, smoking remains the predominant risk factor for SCC of the lung whereas Human Papilloma Virus is the more significant factor for anal and cervical SCC (Zandberg et al., 2013; Lee et al., 2012).

In addition, the dose response gradient $\left(\mathrm{S}_{\mathrm{t}}\right.$ has been modeled as a constant of $1.2 \%$ increase in local control for a $1 \%$ increase in BED. This value was derived from a previous study of randomized trials of head and neck cancer where altered fractionation radiotherapy alone schedules were randomized against conventionally fractionated radiotherapy again delivered as a sole modality (Hartley et al., 2010). The use of this value derived from head and neck cancer can be criticized on the basis of tumoural, environmental and aetiological heterogeneity as above. Furthermore, the above constant was derived from radiotherapy data in the range of 62.1 to $76.8 \mathrm{~Gy}_{10}$ BED. In the current study the radiotherapy dose range was much wider from $45.4 \mathrm{~Gy}_{10}$ in anal cancer to 77.5 $\mathrm{Gy}_{10}$ in cervical cancer. The absence of trials comparing radiotherapy alone schedules in non-head and neck cancer SCC makes the derivation of an appropriate dose gradient in anal, cervical and lung cancer currently impossible. However, the Poisson based model may be used for tumour sites where there is no derivable dose gradient from radiotherapy alone studies.

In head and neck cancer the Poisson model may be of limited value. For example, if we take the trial of Dennis et al. (2004) in head and neck cancer a $26 \%$ increase in local control was seen for the addition of $2.5 \mathrm{~Gy}_{10} \mathrm{BED}$ of chemotherapyccording to the Poisson model. Given the radiotherapy alone component of the treatment contributes $61.7 \mathrm{~Gy}_{10} \mathrm{BED}$, the tBEDc of $2.5 \mathrm{~Gy}_{10}$ represents a $4 \%$ increase in BED. The Poisson model suggests, therefore, a $6.5 \%$ increase in local control for every $1 \%$ increase in BED. In head and neck cancer from radiotherapy alone trials we know this gradient in practice is 1.2 for a value of $\alpha$ of $0.3 \mathrm{~Gy}^{-1}$

A further criticism is that synchronous chemotherapy agents have been considered together with no attempt to account for their possible differing potency or dose intensity. To consider individual agents was impossible given the small number of trials that met the eligibility criteria. Previous modeling work has attempted to derive regime specific tBEDc. For example synchronous platinum doublets were found to have a higher tBEDc than synchronous single agents in head and neck cancer (Pettit et al., 2013).

It is important to note that numerous phase 3 randomised trials identified here were accepted for publication in major journals without the documentation of basic radiotherapy details including radiotherapy fractionation, overall treatment time and the endpoint of local control. Given the localised nature of SCC it is imperative that studies report such data. Furthermore prospective trials should have appropriate radiotherapy quality assurance to permit more reliable modeling. Appendix one provides further details of excluded trials. A further limiting factor for eligibility of studies was the choice of 3 year local control as an endpoint as this excluded many lung and oesophageal studies from the analysis due to the poor prognosis associated with these sub-sites.

In conclusion, remarkable similarities in the values of tBEDc are seen within each model across SCC sub-sites The Poisson model may be preferred for sub-sites where the dose response gradient is not established to avoid reliance on parameters extrapolated from squamous cell carcinoma of the head and neck.

\section{References}

Adelstein, D. J., Lavertu, P., Saxton, J. P., Secic, M., Wood, B. G., Wanamaker, J. R., ... Larto, M. A. (2000). Mature results of a Phase III randomized trial comparing concurrent chemoradiotherapy with radiation therapy alone in patients with Stage III and IV squamous cell carcinoma of the head and neck. Cancer, 88(4), 876-883. http://dx.doi.org/10.1002/(SICI)1097-0142(20000215)88:4<876::AID-CNCR19>3.0.CO;2-Y

Ang, K. K., Harris, J., Wheeler, R., Weber, R., Rosenthal, D. I., Nguyen-Tân, P. F., ... Gillison, M. L. (2010). Human Papillomavirus and Survival of Patients with Oropharyngeal Cancer. $N$ Engl J Med, 363(1), 24-35. http://dx.doi.org/10.1056/NEJMoa0912217

Anonymous. (1996). Epidermoid anal cancer: results from the UKCCCR randomised trial of radiotherapy alone versus radiotherapy, 5-fluorouracil, and mitomycin. UKCCCR Anal Cancer Trial Working Party. UK Co-ordinating Committee on Cancer Research. Lancet, 348(9034), 1049-54.

Auperin, A., Le Pechoux, C., Rolland, E., Curran, W. J., Furuse, K., Fournel, P., ... Pignon, J. P. (2010). 
Meta-Analysis of Concomitant versus Sequential Radiochemotherapy in Locally Advanced Non-Small-Cell Lung Cancer. J Clin Oncol, 28(13), 2181-2190. http://dx.doi.org/10.1200/JCO.2009.26.2543

Bartelink, H., Roelofsen, F., Eschwege, F., Rougier, P., Bosset, J. F., Gonzalez, D. G., ... Pierart, M. (1997). Concomitant radiotherapy and chemotherapy is superior to radiotherapy alone in the treatment of locally advanced anal cancer: results of a phase III randomized trial of the European Organization for Research and Treatment of Cancer Radiotherapy and Gastrointestinal Cooperative Groups. J Clin Oncol, 15(5), 2040-9.

Bosch, F. X., Lorincz, A., Muñoz, N., Meijer, C. J., \& Shah, K. V. (2002). The causal relation between human papillomavirus and cervical cancer. J Clin Path, 55, 244-265. http://dx.doi.org/10.1136/jcp.55.4.244

Cakir, S., \& Egehan, I. (2004). A randomised clinical trial of radiotherapy plus cisplatin versus radiotherapy alone in stage III non-small cell lung cancer. Lung Cancer, 43, 309-316.

Calais, G., Alfonsi, M., Bardet, E., Sire, C., Germain, T., Bergerot, P., ... Bertrand, P. (1999). Randomised Trial of Radiation Therapy versus Concomitant chemotherapy and radiation therapy for advanced-stage oropharynx carcinoma. J Nat Cancer Inst, 91(24), 2081-2086. http://dx.doi.org/10.1093/jnci/91.24.2081

Chemoradiotherapy for Cervical Cancer Meta-Analysis Collaboration. (2008). Reducing Uncertainties about the Effects of Chemoradiotherapy for Cervical Cancer: A Systematic Review and Meta-Analysis of Individual Patient Data from 18 Randomized Trials. $J$ Clin Oncol 26(35), 5802-5812. http://dx.doi.org/10.1200/JCO.2008.16.4368

Dale, R., \& Carabe-Fernandez, A. (2005). The Radiobiology of Conventional Radiotherapy and Its Application to Radionuclide Therapy. Cancer Biother Radiopharm, 20(1), 47-51. http://dx.doi.org/10.1089/cbr.2005.20.47

De Vuyst, H., Clifford, G. M., Nascimento, M. C., Madeleine, M. M., \& Franceschi, S. (2009). Prevalence and type distribution of human papillomavirus in carcinoma and intraepithelial neoplasia of the vulva, vagina and anus: a meta-analysis. Int J Cancer, 124, 1626-1363. http://dx.doi.org/10.1002/ijc.24116

Denis, F., Garaud, P., Bardet, E., Alfonsi, M., Sire, C., Germain, T., ... Calais, G. (2004). Final Results of the 94-01 French Head and Neck Oncology and Radiotherapy Group Randomized Trial Comparing Radiotherapy Alone With Concomitant Radiochemotherapy in Advanced-Stage Oropharynx Carcinoma. $J$ Clin Onc, 22(1), 69-76. http://dx.doi.org/10.1200/JCO.2004.08.021

Eifel, P. J., Winter, K., Morris, M., Levenback, C., Grigsby, P. W., Cooper, J., ... Mutch, D. G. (2004). Pelvic Irradiation With Concurrent Chemotherapy Versus Pelvic and Para-Aortic Irradiation for High-Risk Cervical Cancer: An Update of Radiation Therapy Oncology Group Trial (RTOG) 90-01. J Clin Oncol, 22(5), 872-880.

Forastiere, A. A., Goepfert, H., Maor, M., Pajak, T. F., Weber, R., Morrison, W., ... Cooper J. (2003). Concurrent chemotherapy and radiotherapy for organ preservation in advanced laryngeal cancer. N Engl J Med, 349(22), 2091-98.

Fountzilas, G., Ciuleanu, E., Dafni, U., Plataniotis, G., Kalogera-Fountzila, A., Samantas, E., ... Ghilezan, N. (2004). Concomitant radiochemotherapy vs radiotherapy alone in patients with head and neck cancer: A hellenic cooperative oncology group phase III study. Med Oncol, 21(2), 95-107.

Fowler, J. F., Harari, P. M., Leborgne, F., \& Leborgne, J. H. (2003). Acute radiation reactions in oral and pharyngeal mucosa: tolerable levels in altered fractionation schedules. Radiother Oncol, 69(2), 161-8. http://dx.doi.org/10.1016/S0167-8140(03)00231-7

Geh, J. I., Bond, S. J., Bentzen, S. M., \& Glynne-Jones, R. (2006). Systematic overview of preoperative (neoadjuvant) chemoradiotherapy trials in oesophageal cancer: evidence of a radiation and chemotherapy dose response. Radiother Oncol, 78(3), 236-44. http://dx.doi.org/10.1016/j.radonc.2006.01.009

Glynne-Jones, R., Sebag-Montefiore, D., Adams, R., McDonald, A., Gollins, S., James, R., ... Jitlal, M., \& UKCCCR Anal Cancer Trial Working Party. (2011). "Mind the gap" - The Impact of Variations in the Duration of the Treatment Gap and Overall Treatment Time in the First UK Anal Cancer Trial (ACT 1). Int J Radiat Oncol Biol Phys, 81(5), 1488-94. http://dx.doi.org/10.1016/j.jirobp.2010.07.1995

Grau, C., Prakash Agarwal, J., Jabeen, K., Rab Khan, A., Abeyakoon, S., Hadjieva, T., ... Overgaard, J. (2003). Radiotherapy with or without mitomycin $\mathrm{c}$ in the treatment of locally advanced head and neck cancer: results of the IAEA multicentre randomised trial. Radiother Oncol, 67(1), 17-26.

Hartley, A., Sanghera, P., Glaholm, J., Mehanna, H., McConkey, C., \& Fowler, J. (2010). Radiobiological 
Modelling of the Therapeutic Ratio for the Addition of Synchronous Chemotherapy to Radiotherapy in Locally Advanced Squamous Cell Carcinoma of the Head and Neck. Clin Onc, 22(2), 125-130. http://dx.doi.org/10.1016/j.clon.2009.10.004

Hartley, A., Sanghera, P., Kazi, W., Mehanna, H., McConkey, C., Glaholm, J., \& Fowler, J. (2011). Correlation of Currently Used Radiobiological Parameters with Local Control and Acute and Late Mucosal Toxicity in Randomised Studies of Altered Fractionation for Locally Advanced Head and Neck Cancer. Clin Onc, 23(1), 29-33. http://dx.doi.org/10.1016/j.clon.2010.08.007

Herskovic, A., Martz, K., Al-Sarraf, M., Leichman, L., Brindle, J., Vaitkevicius, V., ... Emami, B. (1992). Combined chemotherapy and radiotherapy compared with radiotherapy alone in patients with cancer of the esophagus. $N$ Engl J Med, 326, 1593-1598. http://dx.doi.org/10.1056/NEJM199206113262403

Jones, B., \& Dale, R. (2005). The Potential for mathematical modeling in the assessment of the radiation dose equivalent of cytotoxic chemotherapy given concomitantly with radiotherapy. $\mathrm{Br} J$ Radiol, 78, 939-44. http://dx.doi.org/10.1259/bjr/40226390

Jones, B., \& Sanghera, P. (2007). Estimation of radiobiologic parameters and equivalent radiation dose of cytotoxic chemotherapy in malignant glioma. Int $J$ Radiat Oncol Biol Phys, 68(2), 441-8. http://dx.doi.org/10.1016/j.ijrobp.2006.12.025

Lee, P. N., Forey, B. A., \& Coombs, K. J. (2012). Systematic review with meta-analysis of the epidemiological evidence in the $1900 \mathrm{~s}$ relating smoking to lung cancer. BMC Cancer, 12, 385. http://dx.doi.org/10.1186/1471-2407-12-385

Morris, M., Eifel, P. J., Lu, J., Grigsby, P. W., Levenback, C., Stevens, R. E., ... Mutch, D. G. (1999). Pelvic Radiation with concurrent chemotherapy compared with pelvic and para-aortic radiation for High-Risk Cervical Cancer. N Engl J Med, 340(15), 1137-43.

Olmi, P., Crispino, S., Fallai, C., Torri, V., Rossi, F., Bolner, A., ... Marsoni, S. (2003). Locoregionally advanced carcinoma of the oropharynx: conventional radiotherapy vs. accelerated hyperfractionated radiotherapy vs. concomitant radiotherapy and chemotherapy-a multicenter randomized trial. Int J Radiat Oncol Biol Phys, 55(1), 78-92.

Olmi, P., Crispino, S., Fallai, C., Torri, V., Rossi, F., Bolner, A., ... Marsoni, S. (1995). Phase III Trial of Thoracic irraditation With or Without Cisplatin for Locally Advanced Unresectable Non-Small-Cell Lung Cancer: A Hoosier Oncology Group Protocol. J Clin Oncol, 13, 1425-1429.

Pearcey, R., Brundage, M., Drouin, P., Jeffrey, J., Johnston, D., Lukka, H., ... Tu, D. (2002). Phase III Trial Comparing Radical Radiotherapy With and Without Cisplatin Chemotherapy in Patients with Advanced Squamous Cell Cancer of the Cervix. J Clin Oncol, 20, 966-972.

Pettit, L., Meade, S., Sanghera, P., Glaholm, J., Geh, J. I., \& Hartley, A. (2013). Can radiobiological parameters derived from squamous cell carcinoma of the head and neck be used to predict local control in anal cancer treated with chemoradiation? Br J Radiol, 86(1021), 20120372. http://dx.doi.org/10.1259/bjr.20120372

Pignon, J. P., le Maître, A., Maillard, E., Bourhis, J., \& MACH-NC Collaborative Group. (2009) MACH-NC Collaborative Group. Meta-analysis of chemotherapy in head and neck cancer (MACH-NC): An update on 93 randomised trials and 17,346 patients. Radiother Oncol, 92(1), 4-14. http://dx.doi.org/10.1016/j.radonc.2009.04.014

Potter, R., Haie-Meder, C., Van Limbergen, E., Barillot, I., De Brabandere, M., Dimopoulos, J., ... Kirisits, C., GEC ESTRO Working Group. (2006). Recommendations from gynaecological (GYN) GEC ESTRO working group (II): Concepts and terms I 3D image-based treatment planning in cervix brachytherapy - 3D dose volume parameters and aspects of 3D image based anatomy, radation physics, radiobiology. Radiother Oncol, 78, 66-77. http://dx.doi.org/10.1016/j.radonc.2005.11.014

Zandberg, D. P., Bhargave, R., Badin, S., \& Cullen, K. J. (2013). The role of human papilloma virus in non-genital cancers. Ca Cancer J Clin, 63(1), 57-81. http://dx.doi.org/10.3322/caac.21167

Zatloukal, P., Petruzelka, L., Zemanova, M., Havel, L., Janku, F., Judas, L., ... Pecen, L. (2004). Concurrent versus sequential chemoradiotherapy with cisplatin and vinorelbine in locally advanced non-small cell lung cancer: a randomised study. Lung Cancer, 46, 87-98. 
Appendix 1. Excluded randomised trials of conventionally fractionated radiotherapy versus chemoradiotherapy in squamous cell carcinoma

\begin{tabular}{|c|c|c|c|}
\hline Author & Year & Journal & Reason for exclusion \\
\hline \multicolumn{4}{|l|}{ Oesophagus } \\
\hline Araújo & 1991 & Cancer & Chemotherapy: included Bleomycin. \\
\hline Herskovic & 1992 & NEJM & Different Radiotherapy doses (50 Gy versus 64 Gy in 2 Gy fractions) \\
\hline Rousell & 1994 & Proc Am Soc Clin Oncol & Abstract only \\
\hline Slabber & 1998 & Am J Clin Oncol & No 3-year LC. \\
\hline Smith & 1998 & Int J Radiat Oncol Biol Phys & Evaluated for surgery after $40 \mathrm{~Gy}$. No LC reported. \\
\hline \multicolumn{4}{|l|}{ SCCHN } \\
\hline Browman & 1994 & $\mathrm{JCO}$ & No 3-year LC. \\
\hline Kumar & 1996 & Acta Oncol & Chemotherapy $=$ Cyclophosphamide, methotrexate, $5-\mathrm{FU}$ \\
\hline Haffty & 1997 & $\mathrm{JCO}$ & $\begin{array}{l}\text { Chemotherapy: mitomycin/dicumarol, included pre-operative and post } \\
\text {-operative patients }\end{array}$ \\
\hline Zakotnik & 1998 & Int J Radiat Oncol Biol Phys & Chemotherapy: MMC and Bleomycin. \\
\hline Adelsteine & 2000 & Am Cancer Soc & $\begin{array}{l}\text { No absolute LC, reported as: likelihood of local disease control without the } \\
\text { need for surgical resection. }\end{array}$ \\
\hline Lartigau & 2003 & Int J Radiat Oncol Biol Phys & Agent: porfiromycin \\
\hline Lefebvre & 2009 & J Nat Cancer Inst & Alternating versus Sequential chemotherapy. \\
\hline Tobias & 2010 & Lancet Oncol & Chemotherapy: methotrexate, 5-FU, vincristine and Bleomycin. \\
\hline \multicolumn{4}{|l|}{ Lung } \\
\hline Landgren & 1973 & Radiology & Chemotherapy: Procarbazine \\
\hline Landgren & 1974 & Cancer & Chemotherapy: Hydroxyurea \\
\hline Dillman & 1990 & NEJM & Induction chemotherapy \\
\hline Le Chevalier & 1991 & J Natl Cancer Inst & Chemotherapy: vindesine, cyclophosphamide, cisplatin, lomustine. \\
\hline Schaake-Koning & 1992 & NEJM & No 3-year LC \\
\hline Trovo & 1992 & Int J Radiat Oncol Biol Phys & No 3-year LC \\
\hline Clamon & 1999 & $\mathrm{JCO}$ & No 3-year LC \\
\hline Furuse & 1999 & $\mathrm{JCO}$ & Sequential versus concurrent chemotherapy \\
\hline Guschall & 2000 & Lung Cancer & Abstract only. Chemotherapy: Ifosphomide. \\
\hline Isaković-Vidović & 2002 & J BUON & Different radiotherapy doses ( $55 \mathrm{~Gy}$ in 20 fractions, $60 \mathrm{~Gy}$ in 30 fractions) \\
\hline Groen & 2004 & Ann Oncol & No 3-year LC \\
\hline Fournel & 2005 & $\mathrm{JCO}$ & Sequential versus concurrent chemotherapy \\
\hline Dasgupta & 2006 & J Cancer Res Ther & Different Radiotherapy doses (65 Gy, 60 Gy and 50 Gy) \\
\hline \multicolumn{4}{|l|}{ Cervix } \\
\hline Piver & 1977 & Am J Obstet Gynecol & Chemotherapy: Hydroxyurea \\
\hline Piver & 1983 & Am J Obstet Gynecol & Chemotherapy: Hydroxyurea \\
\hline Singh & 1985 & $\begin{array}{l}\text { Southeast Asian J Trop Med } \\
\text { Public Health }\end{array}$ & Chemotherapy: Bleomycin \\
\hline Wong & 1989 & Gynecol Oncol & No LC percentage \\
\hline Tattersall & 1992 & Int J Gynecol Cancer & Chemotherapy: Cisplatin, Vinblastine and Bleomycin \\
\hline Stehman & 1993 & $\mathrm{JCO}$ & Hydroxyurea, misonidazole with radiotherapy \\
\hline
\end{tabular}




\begin{tabular}{llll}
\hline Chiara & 1994 & Am J Clin Onc & No 3-year LC percentage \\
Tseng & 1997 & Gynecol Oncol & Chemotherapy: Cisplatin, Vincristine and Bleomycin \\
Grigsby & 1999 & Int J Radiat Oncol Biol Phys & Radiotherapy + / - Misonidazole \\
Keys & 1999 & NEJM & Stage Ib: Radiotherapy versus chemoradiotherapy followed by Hysterectomy \\
Rose & 1999 & NEJM & Chemoradiotherapy: Hydroxyurea included \\
Whitney & 1999 & JCO & Chemoradiotherapy: Hydroxyurea included \\
Wong & 1999 & JCO & Chemotherapy: Epirubicin \\
Onishi & 2000 & Cancer J Sci Am & Intra-arterial chemotherapy \\
Peters & 2000 & JCO & $\begin{array}{l}\text { Adjuvant Chemoradiotherapy versus adjuvant radiotherapy following radical } \\
\text { surgery }\end{array}$ \\
Roberts & 2000 & Int J Cancer & Different radiotherapy doses per stage: 40-46 Gy, 10 Gy parametrial boost \\
Lorvidhaya & 2003 & Int J Radiat Oncol Biol Phys & Adjuvant chemotherapy included, no OTT reported \\
Singh TT & 2003 & Indian J Cancer & No LC percentage \\
Kantardzic & 2004 & Med Arh & Chemotherapy: Cisplatin and Bleomycin. Article in Bosnian. \\
\hline
\end{tabular}

Key: $\mathrm{SCCHN}=$ Squamous cell carcinoma of the head and neck, LC $=$ local control, 5-FU $=5$-flurouricil, MMC $=$ mitomycin-C, RT = radiotherapy, $\mathrm{CRT}=$ Chemoradiotherapy, Gy $=$ Gray, OTT $=$ overall treatment time.

\section{Copyrights}

Copyright for this article is retained by the author(s), with first publication rights granted to the journal.

This is an open-access article distributed under the terms and conditions of the Creative Commons Attribution license (http://creativecommons.org/licenses/by/3.0/). 